\title{
Suspected testicular torsion in children: diagnostic dilemma and recommendation for a lower threshold for initiation of surgical exploration
}

This article was published in the following Dove Press journal: Research and Reports in Urology

Tariq O Abbas ${ }^{1-3}$

Mohammed Abdelkareem ${ }^{4}$

Abdelrahman Alhadi ${ }^{4}$

Vishwanatha Kini ${ }^{5}$

Prem Chandra ${ }^{6}$

Abdulla Al-Ansari ${ }^{4}$

Mansour Ali'

'Department of Pediatric Surgery, Hamad General Hospital, Doha,

Qatar; ${ }^{2}$ College of Medicine, Qatar University, Doha, Qatar; ${ }^{3}$ Weill

Cornell Medical College-Qatar, Doha, Qatar; ${ }^{4}$ Urology Department, Hamad

General Hospital, Doha, Qatar;

${ }^{5}$ Radiology Department, Hamad

General Hospital, Doha, Qatar;

${ }^{6}$ Medical Research Center, Hamad

Medical Corporation, Doha, Qatar
Correspondence: Tariq O Abbas Pediatric Surgery Department, Hamad General Hospital, PO Box 3050, Al-Rayyan Street, Doha, Qatar Tel +9745509365I

Email tabbas@hamad.qa
Purpose: Testicular torsion (TT) represents a clinical challenge that needs emergency surgical assessment. It is common to have negative scrotal exploration due to confounding symptoms and signs which makes it sometimes difficult to differentiate from similar surgical emergencies that do not warrant surgery. At the same time, several occasions of misdiagnoses or late interventions occur with devastating effects. We aim at delineating the significance of the different clinical, laboratory, and radiological variables in the detection of TT.

Methods: We retrospectively reviewed the charts of 52 patients who were surgically explored with a preoperative working diagnosis of suspected TT in our center over the period from 2011 to 2015. All the patients were examined by pediatric surgeons in the emergency room and had undergone ultrasound imaging of the testes. The ultrasound images were retrospectively reviewed by a pediatric radiologist who was blinded to the intraoperative findings. Univariate and multivariate and logistic regression analyses were performed.

Results: Of the studied group of patients, the majority (84.6\%) had TT upon surgical exploration. The most frequently presented symptom was pain (80.8\%), and only a minority (11.5\%) presented with vomiting. Radiological findings with the highest sensitivity were heterogeneous echogenicity in favor of TT and enlarged epididymis indicating that TT is unlikely. However, the predictability of TT by any of the assessed clinical and imaging factors was statistically insignificant.

Conclusion: It is important to gather all relevant data from clinical, laboratory, and imaging sources when assessing pediatric patients with suspected TT given the inaccuracy of each single one of them if used alone. Keeping this in mind, Doppler ultrasound has a significant role to aid in the accuracy of the diagnosis and hence the appropriate decision-making thereafter. However, we found no single clinical or imaging sign that is sensitive enough to prove or rule out TT. Therefore, surgical exploration should take place in a timely manner. Moreover, further research is necessary to construct scoring systems where different predictors collectively have higher reliability.

Keywords: testicular torsion, Doppler ultrasound, children, spermatic cord torsion, diagnosis

\section{Introduction}

Testicular torsion (TT) is considered a surgical emergency that, in case of delay or misdiagnosis, can lead to the loss of the affected testis and therefore mandates an emergency assessment and a possible surgical intervention. ${ }^{1}$ It accounts for $10 \%-15 \%$ of "acute scrotal" conditions in children ${ }^{2,3}$ with an annual incidence of 3.8 per 100,000 pediatric patients. ${ }^{4}$ Acute scrotal pain, which is the most frequent presenting symptom in these cases, can be caused by other conditions that do not need surgical exploration, such as torsion of the appendix testis, acute scrotal edema, and epididymo-orchitis 
(EDO). However, timely assessment and intervention are crucial in the scenario of a real TT to achieve a higher rate of testicular salvageability..$^{5-7}$

On the other hand, physical examination represents a corner stone in the assessment of a patient with suspected TT. High-yield clinical findings include transverse testicular position, absent or diminished cremasteric reflex, and high-riding testis. ${ }^{5,6,8}$ However, these signs can be masked or overlapped by the other conditions mentioned above, which mimic TT. ${ }^{9}$ Moreover, the sensitivity and accuracy of the clinical evaluation can be strongly jeopardized by the distressed patients rendering the diagnosis of TT sometimes very doubtful, particularly in children. ${ }^{2,10,11}$

Because of these difficulties in the diagnosis of TT, radiological assessment is utilized frequently in the situations of suspected TT to differentiate between these similar conditions. Doppler ultrasound (DUS) has been considered the standard imaging tool for the assessment of TT with high sensitivity and specificity. ${ }^{12-14}$ However, the decision to proceed to imaging should be tackled critically and cautiously to avoid any delay in the surgical intervention when doubt about the presence of TT does not exist. Delay and errors associated with DUS imaging have led to the utilization of newer approaches, including scintigraphy, magnetic resonance imaging, and near-infrared spectroscopy. ${ }^{15-17}$ To date, no systematic approach has been established for the objective analysis of acute scrotum without complementary examinations. We would like to explore the predictability of the different clinical and imaging signs in the diagnosis of TT.

\section{Methods}

\section{Study design and participants}

This is a retrospective study of all patients aged $0-14$ years, who were operated on at Hamad General Hospital, Doha, Qatar, between January 2011 and December 2015 with suspected TT. This study was approved by the Medical Research Center of the Hamad Medical Corporation (number: 16309/16). The requirement for patient consent was waived because of the retrospective nature of the study. This study was carried out in accordance with the principles of the Declaration of Helsinki.

\section{Study measures and data variables}

The charts of the patients who met the inclusion criteria were reviewed. Presenting symptoms and clinical findings as documented by the admitting pediatric surgeons were collected. Moreover, the anthropometric measurements of the patients including the height, weight, and body mass index were checked, and routine blood investigations were carried out. However, DUS images of the testes were reviewed by a pediatric radiologist who was blinded to the subsequent intraoperative findings. The operative notes were reviewed for diagnosis, viability of the testes, intervention performed, and preoperative and postoperative complications.

All the included patients had been explored surgically after having their history taken from them (or their parents), been physically examined, and undergone DUS of the testes. Surgery was decided because of inability to rule out TT and was routinely performed with the patient in a supine position and under general anesthesia. The scrotum was explored routinely through a midline raphe incision. When there was TT, the testis was detwisted and set in warm, clammy wipes for 15-20 minutes; in the situation that it was clearly nonviable, it was evacuated. If the testis was reperfused or bleeding could be seen from a cut surface of the tunica albuginea, it was replaced back in the scrotum and settled in with nonabsorbable sutures using 3-point fixation. The contralateral testis fixation was performed routinely in the similar manner.

\section{Statistical analysis}

The aim behind analyzing the different collected variables in this study is to determine which factors have higher predictive values to confirm (or rule out) TT prior to the surgical exploration. For this purpose, the sensitivity, specificity, and positive and negative predictive values of these parameters were calculated, using surgical exploration as the point of reference. A receiver operating characteristic (ROC) curve was calculated using significant predictors (as determined via multivariate regression analysis) to derive best suitable cutoff values and to assess model discrimination and predictive accuracy. ROC curves provide a comprehensive and visually attractive way to summarize the accuracy of predictions.

Associations between two or more qualitative variables were assessed using chi-squared test and Fisher's exact test as appropriate. Univariate and multivariate logistic regression methods were used to assess the predictive values of each predictor or the risk factors (clinical signs and symptoms, physical examination, and radiological findings) for explored patients with suspected TT. For multivariate regression models, variables were considered if statistically significant at the $P<0.05$ level in univariate analysis or if determined to be clinically important.

The results of the logistic regression analyses were reported as OR with $95 \%$ CI. A number of risk factors identified in multivariable logistic regression analyses were used to compute weighted risk score and generate a clinically 
applicable decision-making rule for the prediction of TT. Pictorial presentations of the key results were made using appropriate statistical graphs. A two-sided $P$-value $<0.05$ was considered to be statistically significant.

All statistical analyses were conducted using statistical packages SPSS Version 22.0 (SPSS Inc., Chicago, IL, USA) and Epi Info ${ }^{\mathrm{TM}} 2000$ (Centers for Disease Control and Prevention, Atlanta, GA, USA).

\section{Results}

\section{Clinical symptoms and signs and laboratory workup}

In total, 52 patients were included in this study over the specified study period. Pain was the most frequent modality of presentation and occurred in 42 patients $(80.8 \%)$ of the study population (Table 1). The remaining patients had been brought to medical attention because of other complaints including scrotal swelling which happened in about half of the patients. However, pain occurred less frequently in patients with TT than in those without TT ( $81 \%$ vs $100 \%$, respectively). On the other hand, vomiting only occurred in six of the studied patients (11.5\%), and almost no difference was detected between those with TT and those without $(11.4 \%$ and $12.5 \%$, respectively; Table 2 ). The logistic regression analysis was performed considering several potential clinical predictors possibly associated with TT. Tables 2-4 present the results of logistic regression analysis testing for each predictive variable and its association with TT. The results were presented with OR and associated 95\% CI. Children having TT proven following surgical exploration were slightly older (mean age $=7.97$ vs 6.62 years) and have higher weight ( mean $=25 \mathrm{vs} 20 \mathrm{~kg}$ ). In addition, those with TT had longer duration of pain, time to accidents and emergencies (A\&E), and time from $A \& E$ to operation room. However, these differences were statistically insignificant $(P>0.05$; Figure 1)

There were different clinical signs that were of importance in this study. For example, tenderness ( $\mathrm{OR}=4.63$; 95\% CI $[0.41,52.75] ; P=0.390)$ was more common in TT patients $(65.9 \%$ vs $50 \%)$ with a positive predictive value (PPV) of 87.9. However, variation between the two groups (TT vs non-TT) in regard to the presence of scrotal erythema was less distinctive as it was noticed in $65.9 \%$ of patients with TT, while $50 \%$ of patients without TT only had erythema.

Complete blood counts and differential counts were requested routinely for all the patients with suspected TT and white blood cells slightly higher (61\%) in comparison with those without TT (57\%), and the difference was not statistically significant $(P=0.844)$. However, urine analysis was found to be recorded only for 12 patients of the study group, of which one was having pyuria.

\section{DUS findings}

Although the absence of testicular blood flow was an important predictor for the diagnosis of TT, $11.9 \%$ of the patients surgically proven to have TT in our study had no absence of vascularity. A striking feature in ultrasonography examination of these patients is the finding of heterogeneous echogenicity in patients with TT $(61.8 \%)$ in contrast to those without TT (37.5\%; OR $=10.32 ; 95 \%$ CI $[0.47,228.8] ; P=0.212)$, and this has carried the highest PPV among other radiological parameters $(87.5 \%)$. The patients presented with enlarged epididymis $(\mathrm{OR}=2.06 ; 95 \%$ CI $[0.13,33.94] ; P=0.697)$ and reactive hydrocele $(\mathrm{OR}=1.83 ; 95 \% \mathrm{CI}[0.18,18.19]$; $P=0.412$ ) were positively associated with an increased risk for TT; however, the differences were also noted to be statistically insignificant $(P>0.05)$.

In the multivariable logistic regression analysis controlling for all other potential covariates considered in the univariate logistic regression analysis, two radiological predictors, heterogeneous echogenicity (adjusted $\mathrm{OR}=5.69$; $95 \%$ CI $[0.59,55.19] ; P=0.133)$ but not increased blood flow to $\mathrm{EP}$ (adjusted OR $=0.11 ; 95 \%$ CI $[0.01,1.23] ; P=0.072$ ), remained associated with TT ( $P>0.05$; . Tables 3 and 4). The sample size was small, and CIs were wide in most of the subgroups (in both univariate and multivariate logistic regression analyses), suggesting that the study was underpowered to detect a difference.

The discriminative ability of the model was found to be good with an area under the ROC curve value of 0.83 $(95 \%$ CI $[0.71,0.95])$. The sensitivity and specificity values at a cutoff predictive probability score point of $\geq 0.70$ were $78.8 \%$ and $63 \%$ and at a cutoff score point of $\geq 0.80$ were $73 \%$ and $88 \%$ (positive likelihood ratio $=5.8$ ), respectively (Figure 2; Table 5).

\section{Discussion}

TT is considered a surgical emergency that warrants an immediate exploration. Prior to the use of the DUS in the management of these cases, most of the patients were taken for operative intervention with high rates of negative exploration that reached about two-thirds of the cases with associated morbidity as well as the high costs of care related to this. ${ }^{18,19}$ Therefore, the utilization of further imaging, particularly DUS, has helped to filter more accurately those who do need surgical intervention ${ }^{20}$ although, unfortunately, this can cause sometimes a significant delay in the surgery that can reduce 
Table I Clinical, laboratory, radiological, and surgical findings of the patients

\begin{tabular}{|c|c|c|c|c|c|}
\hline Characteristics & $\mathbf{N}$ & Frequency (\%) & Characteristics & $\mathbf{N}$ & Frequency (\%) \\
\hline \multicolumn{6}{|c|}{ Clinical symptoms and signs } \\
\hline $\begin{array}{l}\text { Pain } \\
\text { Yes } \\
\text { No } \\
\end{array}$ & 52 & $\begin{array}{l}42(80.8) \\
10(19.2)\end{array}$ & $\begin{array}{l}\text { Vomiting } \\
\text { Yes } \\
\text { No } \\
\end{array}$ & 52 & $\begin{array}{l}6(11.5) \\
46(88.5)\end{array}$ \\
\hline $\begin{array}{l}\text { Other } \\
\text { symptoms } \\
\text { Yes } \\
\text { No }\end{array}$ & 52 & $\begin{array}{l} \\
\text { I }(1.9) \\
51(98.1)\end{array}$ & $\begin{array}{l}\text { Swelling } \\
\text { Yes } \\
\text { No }\end{array}$ & 52 & $\begin{array}{l}27(51.9) \\
25(48.1)\end{array}$ \\
\hline $\begin{array}{l}\text { Erythema } \\
\text { Yes } \\
\text { No }\end{array}$ & $5 I$ & $\begin{array}{l}21(4 I .2) \\
30(58.8)\end{array}$ & $\begin{array}{l}\text { Scrotal edema } \\
\text { Yes } \\
\text { No } \\
\end{array}$ & 42 & $\begin{array}{l}17(40.5) \\
25(59.5) \\
\end{array}$ \\
\hline $\begin{array}{l}\text { Tenderness } \\
\text { Yes } \\
\text { No }\end{array}$ & 52 & $\begin{array}{l}33(63.5) \\
137(36.5)\end{array}$ & & & \\
\hline \multicolumn{6}{|c|}{ Laboratory investigations } \\
\hline $\begin{array}{l}\text { Pyuria } \\
\text { Yes } \\
\text { No } \\
\end{array}$ & 12 & $\begin{array}{l}\text { I (8.3) } \\
\text { II (9I.7) }\end{array}$ & $\begin{array}{l}\text { WBC }(>10.000) \\
\text { Yes } \\
\text { No }\end{array}$ & 43 & $\begin{array}{l}26(60.5) \\
17(39.5)\end{array}$ \\
\hline $\begin{array}{l}\text { CRP } \\
\text { Yes } \\
\text { No }\end{array}$ & 5 & $\begin{array}{l}2(40) \\
3(60)\end{array}$ & & & \\
\hline \multicolumn{6}{|l|}{ Radiological findings } \\
\hline $\begin{array}{l}\text { Increased } \\
\text { echogenicity } \\
\text { Yes } \\
\text { No } \\
\end{array}$ & 42 & $\begin{array}{l} \\
2(4.8) \\
40(95.2) \\
\end{array}$ & \begin{tabular}{|l|} 
Decreased \\
echogenicity \\
Yes \\
No \\
\end{tabular} & 42 & $\begin{array}{l}\text { II (26.2) } \\
3 \text { I (73.8) } \\
\end{array}$ \\
\hline $\begin{array}{l}\text { Heterogeneous } \\
\text { echogenicity } \\
\text { Yes } \\
\text { No } \\
\end{array}$ & 42 & $\begin{array}{l}24(57.1) \\
18(42.9) \\
\end{array}$ & $\begin{array}{l}\text { Homogenous } \\
\text { echogenicity } \\
\text { Yes } \\
\text { No } \\
\end{array}$ & 42 & $\begin{array}{l}\text { II (26.2) } \\
31(73.8) \\
\end{array}$ \\
\hline $\begin{array}{l}\text { No blood flow } \\
\text { Yes } \\
\text { No }\end{array}$ & 42 & $\begin{array}{l}37(88.1) \\
5(11.9) \\
\end{array}$ & $\begin{array}{l}\text { Atrophy } \\
\text { Yes } \\
\text { No }\end{array}$ & 45 & $\begin{array}{l}13(28.9) \\
32(71.1)\end{array}$ \\
\hline $\begin{array}{l}\text { Reactive } \\
\text { hydrocele } \\
\text { Yes } \\
\text { No }\end{array}$ & 42 & $\begin{array}{l}23(54.8) \\
19(45.2)\end{array}$ & $\begin{array}{l}\text { Increased } \\
\text { blood flow EP } \\
\text { Yes } \\
\text { No }\end{array}$ & 42 & $\begin{array}{l}\text { II (26.2) } \\
31(73.8)\end{array}$ \\
\hline $\begin{array}{l}\text { Enlarged EP } \\
\text { Yes } \\
\text { No }\end{array}$ & 42 & $\begin{array}{l}26(61.9) \\
16(38.1) \\
\end{array}$ & & & \\
\hline \multicolumn{6}{|l|}{ Surgical findings } \\
\hline $\begin{array}{l}\text { Testicular torsion } \\
\text { Yes } \\
\text { No }\end{array}$ & 52 & $\begin{array}{l}44(84.6) \\
8(15.4)\end{array}$ & $\begin{array}{l}\text { Testicular appendage } \\
\text { torsion } \\
\text { Yes } \\
\text { No } \\
\end{array}$ & 52 & $\begin{array}{l}2(3.8) \\
50(96.2)\end{array}$ \\
\hline $\begin{array}{l}\text { Ischemic } \\
\text { torsion } \\
\text { Yes } \\
\text { No } \\
\end{array}$ & 46 & $\begin{array}{l}35(76.1) \\
\text { II (23.9) }\end{array}$ & $\begin{array}{l}\text { Gangrenous } \\
\text { torsion } \\
\text { Yes } \\
\text { No } \\
\end{array}$ & 46 & $\begin{array}{l}9(19.6) \\
37(80.4)\end{array}$ \\
\hline $\begin{array}{l}\text { EDO } \\
\text { Yes } \\
\text { No }\end{array}$ & 52 & $\begin{array}{l}2(3.8) \\
50(96.2)\end{array}$ & $\begin{array}{l}\text { Readmission } \\
\text { Yes } \\
\text { No }\end{array}$ & 45 & $\begin{array}{l}3(6.7) \\
42(93.3)\end{array}$ \\
\hline
\end{tabular}

Notes: For some parameters, sum may not be equal to the total number $n=52$, due to some missing observations. All the percentages (\%) computed were based on nonmissing values.

Abbreviations: CRP, C-reactive protein; EDO, epididymo-orchitis; EP, epididymis; WBC, white blood cells. 
Table 2 Assessment of potential predictors and factors using predictive regression model analysis: association of clinical signs and symptoms and other parameters with testicular torsion (univariate logistic regression analysis)

\begin{tabular}{|c|c|c|c|c|}
\hline Predictor & $\begin{array}{l}\text { Testicular } \\
\text { torsion }(\mathrm{N}=44)\end{array}$ & $\begin{array}{l}\text { Nontesticular } \\
\text { torsion }(\mathrm{N}=8)\end{array}$ & $\begin{array}{l}\text { Unadjusted OR } \\
(95 \% \mathrm{CI})\end{array}$ & $P$-value ${ }^{a}$ \\
\hline \multicolumn{5}{|l|}{ Symptoms and signs } \\
\hline Pain & $34(77.3 \%)$ & $8(100 \%)$ & - & 0.328 \\
\hline Vomiting & $5(11.4 \%)$ & $\mathrm{I}(12.5 \%)$ & $0.19(0.01,8.77)$ & 0.926 \\
\hline Erythema & $17(39.5 \%)$ & $4(50 \%)$ & $0.36(0.03,3.91)$ & $0.58 \mathrm{I}$ \\
\hline Tenderness & $29(65.9 \%)$ & $4(50 \%)$ & $4.63(0.4 I, 52.78)$ & 0.390 \\
\hline \multicolumn{5}{|l|}{ DUS findings } \\
\hline No blood flow & 29 (85.3\%) & $8(100 \%)$ & - & 0.564 \\
\hline $\begin{array}{l}\text { Heterogeneous } \\
\text { echogenicity }\end{array}$ & $21(6 \mathrm{I} .8 \%)$ & $3(37.5 \%)$ & $10.32(0.47,228.8)$ & 0.212 \\
\hline $\begin{array}{l}\text { Homogenous } \\
\text { echogenicity }\end{array}$ & $8(23.5 \%)$ & $3(37.5 \%)$ & $0.75(0.05, \mathrm{II} .4 \mathrm{I})$ & 0.419 \\
\hline Enlarged EP & $21(61.8 \%)$ & $5(62.5 \%)$ & $0.63(0.05,7.37)$ & 0.969 \\
\hline Increased blood flow EP & $8(23.5 \%)$ & $3(37.5 \%)$ & $0.22(0.01,9.95)$ & 0.412 \\
\hline Reactive hydrocele & $19(55.9 \%)$ & $4(50 \%)$ & $1.83(0.18,18.19)$ & 0.764 \\
\hline
\end{tabular}

Note: aPearson chi-squared and Fisher's exact test, logistic regression analysis.

Abbreviations: DUS, Doppler ultrasound; EP, epididymis.

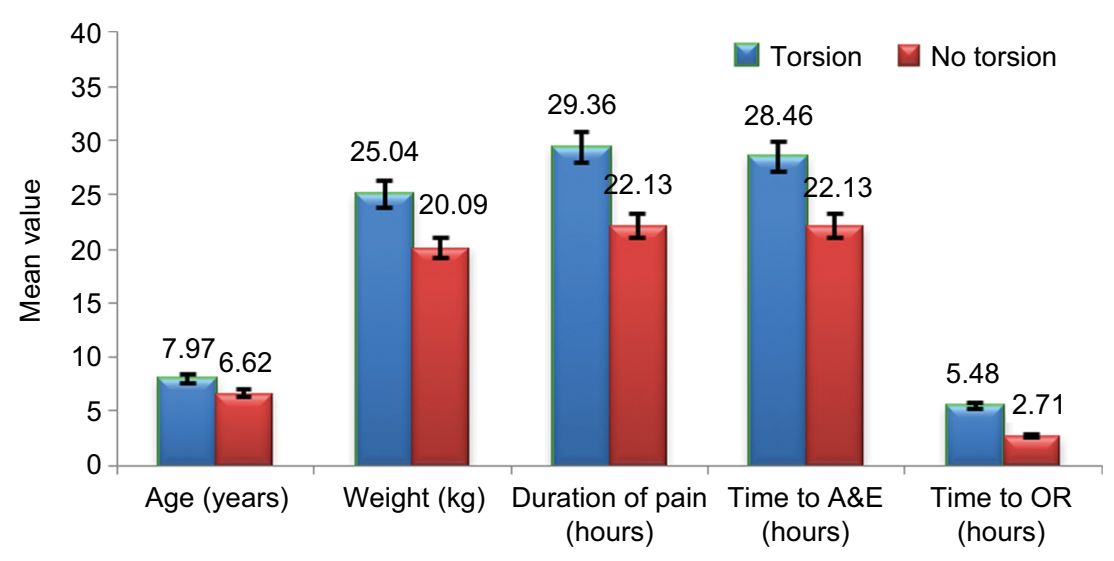

Figure I Comparison of mean values (various variables' demographics and in presentation modalities) between testicular torsion and no torsion groups. Abbreviation: A\&E, accidents and emergencies.

the rates of testicular salvageability. Moreover, radiological imaging is limited by its availability and the expertise of both its operators and evaluators.

The current study is not intended to survey the relative functions of history and physical and radiological examinations, nor endeavor to explain their separate benefits and negative marks. It is an observational review to recognize clinical and radiological examination parameters of relevance in diagnosing TT in pediatric patients with acute scrotal pain. Although signs and symptoms associated with TT are well defined, ${ }^{2,9}$ DUS has become a ubiquitous tool for the differential diagnosis of acute scrotum. ${ }^{12}$ Despite dependence on DUS in day-to-day practice, several studies have attempted to provide physicians with substitutes for the clinical diagnosis of TT. ${ }^{8,21,22}$
Although pain is the most alarming symptom causing patients with suspected TT to seek medical attention, this study showed that only four of every five of these patients (81.1\%) presented with pain. Therefore, the absence of pain should be tackled cautiously in patients with suspected TT, and full physical examination and, whenever needed, imaging should be carried out. On the other hand, vomiting was less frequent in the studied group of patients similar to what have been reported previously in the literature. ${ }^{23}$

Although certain physical examination findings are sufficiently reliable to diagnose TT, such as the absence of cremasteric reflex (92\% sensitive) and anteriorly rotated epididymis (98\% specific), ${ }^{22}$ these signs are difficult to determine retrospectively as they are not frequently looked for and not recorded when detected. However, the presence 
Table 3 Multivariate logistic regression model for determining potential predictors for testicular torsion

\begin{tabular}{|l|l|l|l|l|}
\hline Predictor & Testicular torsion $\mathbf{( N = 4 4 )}$ & Non-testicular torsion (N=8) & Adjusted OR $\left.^{\mathbf{a}} \mathbf{( 9 5 \%} \mathbf{C l}\right)$ & $\mathbf{P}_{\text {-value }}$ \\
\hline Heterogeneous echogenicity & $21(61.8 \%)$ & $3(37.5 \%)$ & $5.69(0.59,55.19)$ & 0.133 \\
Enlarged EP & $8(23.5 \%)$ & $3(37.5 \%)$ & $0.11(0.01,1.23)$ & 0.072 \\
\hline
\end{tabular}

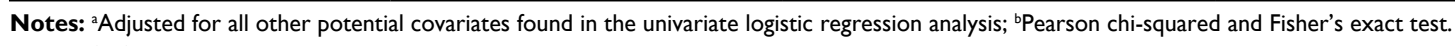

Abbreviation: EP, epididymis.

Table 4 Diagnostic value of clinical signs and symptoms and physical examination findings with potential predictors derived from logistic regression analysis for proven testicular torsion

\begin{tabular}{|c|c|c|c|c|}
\hline Variables & Sensitivity (\%) & Specificity (\%) & PPV (\%) & NPV (\%) \\
\hline \multicolumn{5}{|l|}{ Symptoms and signs } \\
\hline Pain & 77.3 & 0 & 80.9 & 0 \\
\hline Vomiting & 11.4 & 87.5 & 83.3 & 15.2 \\
\hline Erythema & 39.5 & 50 & 81 & 13.3 \\
\hline Tenderness & 65.9 & 50 & 87.9 & 21.1 \\
\hline \multicolumn{5}{|l|}{ DUS findings } \\
\hline No blood flow & 85.3 & 100 & 100 & 61.5 \\
\hline Heterogeneous echogenicity & 61.8 & 62.8 & 87.5 & 27.8 \\
\hline Homogenous echogenicity & 23.5 & 62.5 & 72.7 & 16.1 \\
\hline Enlarged EP & 61.8 & 37.5 & 80.8 & 18.8 \\
\hline Increased blood flow EP & 23.5 & 62.5 & 72.5 & 16.1 \\
\hline Reactive hydrocele & 55.9 & 50 & 82.6 & 21.1 \\
\hline
\end{tabular}

Abbreviations: DUS, Doppler ultrasound; EP, epididymis; NPV, negative predictive value; PPV, positive predictive value.

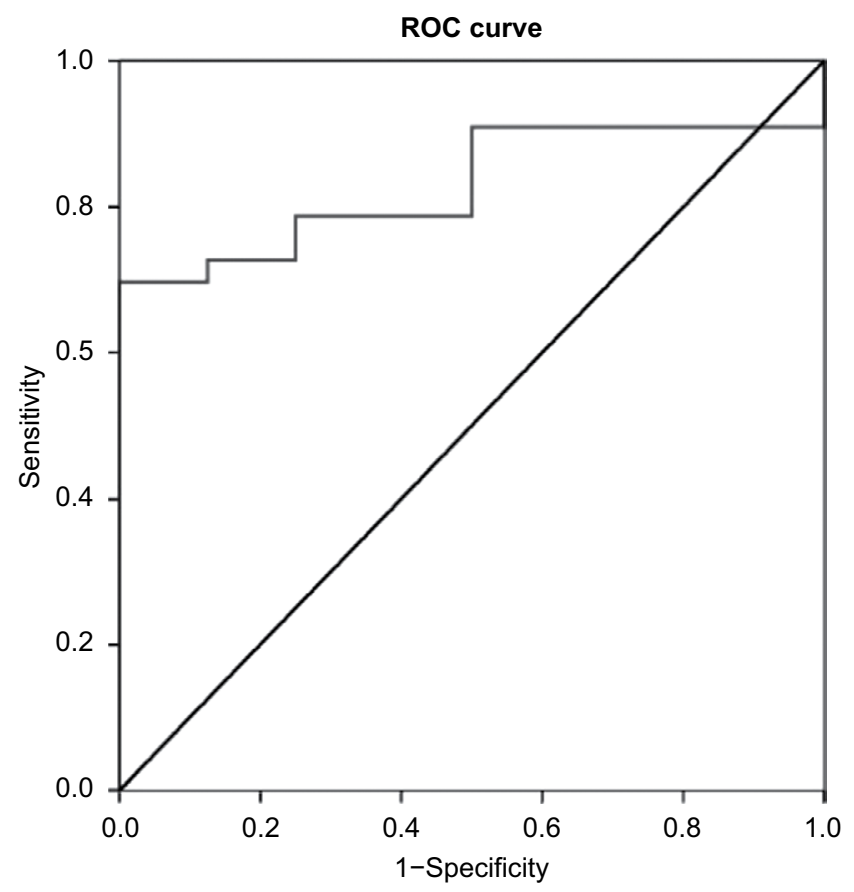

Figure 2 ROC curve using predicted probabilities/risk scores in predictive diagnosis of testicular torsion.

Abbreviation: ROC, receiver operating characteristic.

of both the tenderness and scrotal erythema were clinically valuable signs upon the analysis of our patients' data.

Blood and urine inflammatory markers were used to be high in non-TT patients (including EDO). ${ }^{24}$ Although white blood counts were requested in 43 patients, C-reactive protein results and urine analysis were available only for a minority of them. Recording these biomarkers will strongly be encouraged in the following prospective study.

Debate continues regarding whether DUS should be mandatory for all cases of acute scrotum. ${ }^{12}$ Although the absence of vascularity is an important radiological finding, the presence of blood flow should not rule out TT as $11.9 \%$ of our patients with surgically proven TT had normal vascularity, supporting the results of others. ${ }^{25}$ Moreover, we have found absence of the blood flow in DUS in the eight cases proved not to be TT upon surgical exploration, which could be diminished vascularity and indicate operator variability. On the other hand, the analysis of our data had drawn out attention to the importance of studying the ultrasound echogenicity of the testes in patients with suspected TT. A significant proportion of patients had heterogeneous echogenicity of the affected testes in those with TT (61.8\%) in contrast to those without TT (37.5\%) as the highest PPV to have TT. Hence, it was a valuable marker for the presence of TT rather than unsalvageability of the testes per se as stated previously. ${ }^{26}$ Three terms were used to describe testicular echogenicity according to Chmelnik et al::7 1) normal echogenicity (homogeneous pattern); 2) diffuse hyperechogenicity or hypoechogenicity (homogeneous pattern); and 3) focal hyperechogenicity and/ or hypoechogenicity (heterogeneous pattern). Moreover, 


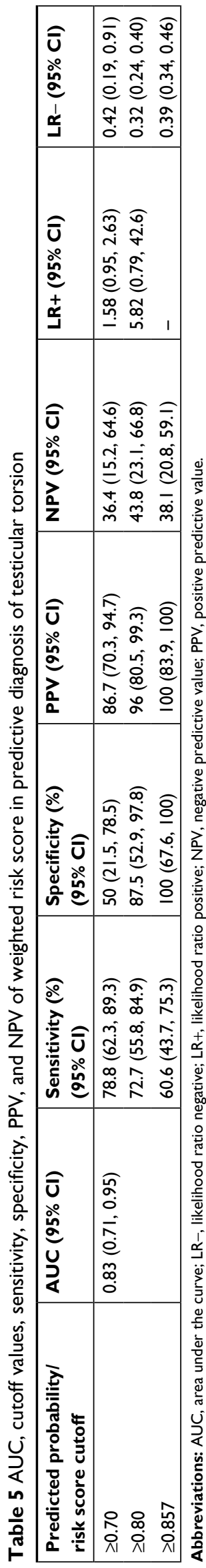

Samson et al demonstrated that "heterogeneity index" is a quantifiable gradation of heterogeneity that can be used as an objective parameter to determine the viability of a torsed testicle. ${ }^{28}$ It is noteworthy that no diagnostic method is free of error, and even DUS may have sensitivity as low as $91 \%{ }^{23,29}$ (Figure 3).

Our study has some limitations including its retrospective nature and the small number of the cases encountered. On

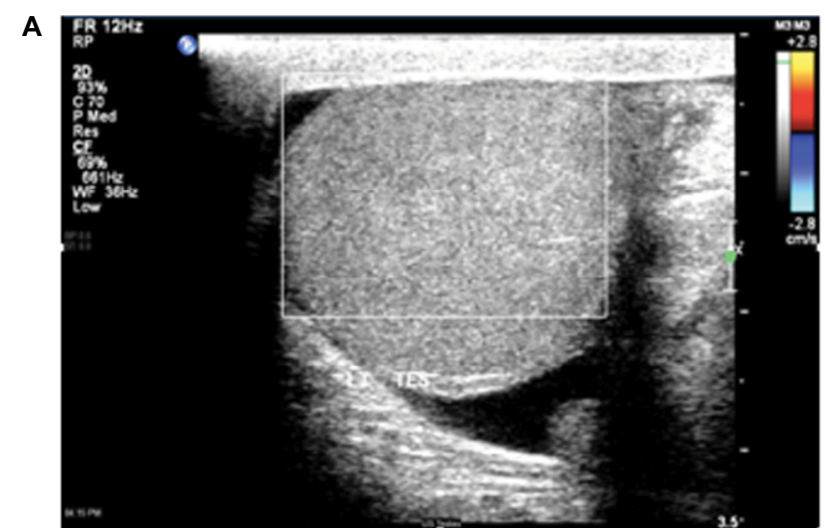

B

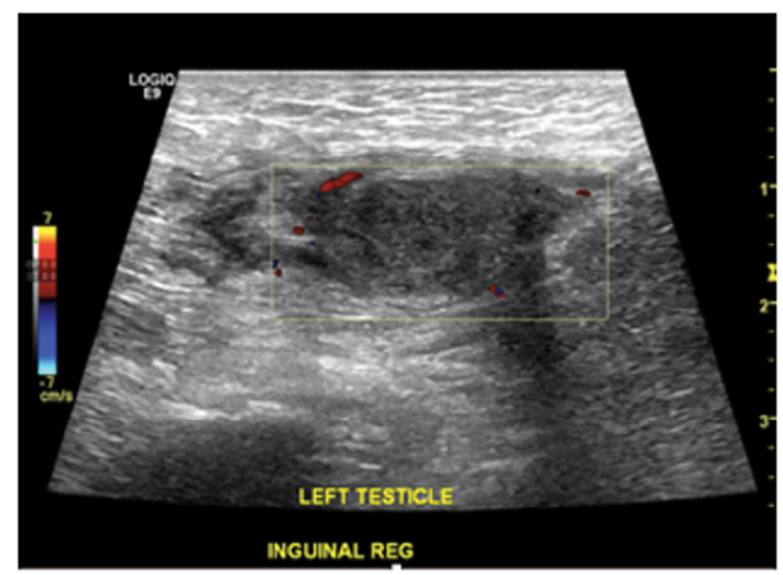

C

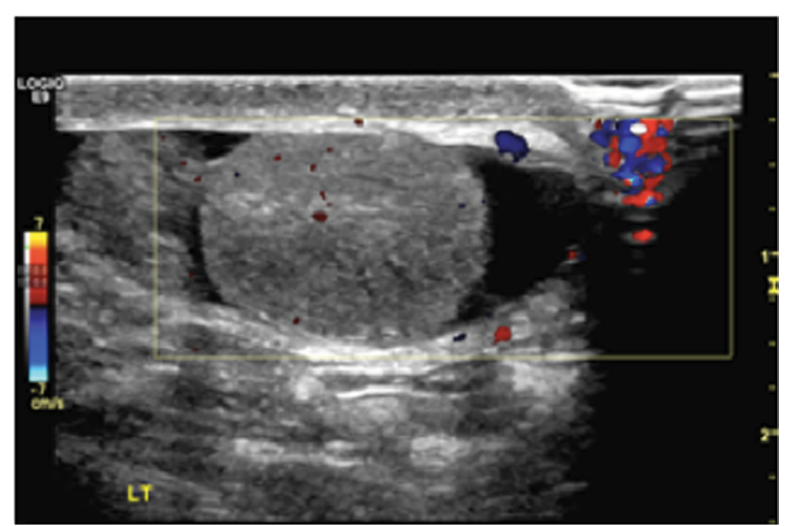

Figure 3 Doppler ultrasound images of testes in three different patients with suspected TT: (A) homogenous echotexture of the testis with absent blood flow and mild reactive hydrocele, who had TT; (B) heterogeneous echogenicity with absent vascularity, who had TT; $(\mathbf{C})$ heterogeneous echotexture with reduced vascularity that turned to be torsion of appendix testis upon surgical exploration. Abbreviation: TT, testicular torsion. 
the other hand, a strength is that all of the data sets included patients from the single tertiary hospital managing pediatric surgical conditions.

\section{Conclusion}

A significant overlap exists between TT and other causes of acute scrotum making the differentiation between them a real clinical challenge with highly serious repercussions. However, testicular salvageability in torsion cases depends on the interval between the onset of pain and surgical intervention. Hence, a thorough clinical and radiological examination of children with acute scrotum is strongly warranted and could help the determination of TT. We found that the presence of tenderness, heterogeneous echogenicity, and the absence of the enlarged EP should warn the care provider of the near certainty of TT, and appropriate management should be expedited in this particular group of patients. The indicative estimation of the reliability of these factors and not others remains to be illustrated. We found no single clinical or imaging feature that is sensitive enough by its own to prove or rule out TT apart from echotexture heterogeneity by ultrasound which is at the same time associated with unsalvageability. Therefore, we do encourage surgical exploration to take place in a timely manner whenever doubt about TT exists. At the same time, the stage is open for the development of a scoring system that cumulatively combines several clinical and radiological variables in a common pool to gain more accurate diagnosis, which is strongly needed.

\section{Acknowledgments}

The publication of this article was funded by the Qatar National Library, Doha, Qatar. This work was funded by the Medical Research Center, Hamad Medical Corporation, Doha, Qatar.

\section{Author contributions}

All authors contributed toward data analysis, drafting and critically revising the paper, gave final approval of the version to be published, and agree to be accountable for all aspects of the work.

\section{Disclosure}

The authors report no conflicts of interest in this work.

\section{References}

1. Barada JH, Weingarten JL, Cromie WJ. Testicular salvage and age-related delay in the presentation of testicular torsion. $J$ Urol. 1989;142(3):746-748.
2. McAndrew HF, Pemberton R, Kikiros CS, Gollow I. The incidence and investigation of acute scrotal problems in children. Pediatr Surg Int. 2002;18(5-6):435-437.

3. Liang T, Metcalfe P, Sevcik W, Noga M. Retrospective review of diagnosis and treatment in children presenting to the pediatric department with acute scrotum. AJR Am J Roentgenol. 2013;200(5):W444-W449.

4. Zhao LC, Lautz TB, Meeks JJ, Maizels M. Pediatric testicular torsion epidemiology using a national database: incidence, risk of orchiectomy and possible measures toward improving the quality of care. $J$ Urol. 2011;186(5):2009-2013.

5. Lewis AG, Bukowski TP, Jarvis PD, Wacksman J, Sheldon CA. Evaluation of acute scrotum in the emergency department. J Pediatr Surg. 1995;30(2):277-282.

6. Davenport M. ABC of general surgery in children. Acute problems of the scrotum. BMJ. 1996;312(7028):435-437.

7. Nöske HD, Kraus SW, Altinkilic BM, Weidner W. Historical milestones regarding torsion of the scrotal organs. J Urol. 1998;159(1):13-16.

8. Beni-Israel T, Goldman M, Bar Chaim S, Kozer E. Clinical predictors for testicular torsion as seen in the pediatric ED. Am J Emerg Med. 2010;28(7):786-789.

9. Nelson CP, Williams JF, Bloom DA. The cremasteric reflex: a useful but imperfect sign in testicular torsion. J Pediatr Surg. 2003;38(8):1248-1249.

10. Livne PM, Sivan B, Karmazyn B, Ben-Meir D. Testicular torsion in the pediatric age group: diagnosis and treatment. Pediatr Endocrinol Rev. 2003;1(2):128-133.

11. Schmitz D, Safranek S. Clinical inquiries. How useful is a physical exam in diagnosing testicular torsion? J Fam Pract. 2009;58(8):433-434.

12. Liguori G, Bucci S, Zordani A, et al. Role of US in acute scrotal pain. World J Urol. 2011;29(5):639-643.

13. al Mufti RA, Ogedegbe AK, Lafferty K. The use of Doppler ultrasound in the clinical management of acute testicular pain. Br J Urol. 1995;76(5):625-627.

14. Yazbeck S, Patriquin HB. Accuracy of Doppler sonography in the evaluation of acute conditions of the scrotum in children. J Pediatr Surg. 1994;29(9):1270-1272.

15. Nussbaum Blask AR, Bulas D, Shalaby-Rana E, Rushton G, Shao C, Majd M. Color Doppler sonography and scintigraphy of the testis: a prospective, comparative analysis in children with acute scrotal pain. Pediatr Emerg Care. 2002;18(2):67-71.

16. Mäkelä E, Lahdes-Vasama T, Ryymin P, et al. Magnetic resonance imaging of acute scrotum. Scand J Surg. 2011;100(3):196-201.

17. Aydogdu O, Burgu B, Gocun PU, et al. Near infrared spectroscopy to diagnose experimental testicular torsion: comparison with Doppler ultrasound and immunohistochemical correlation of tissue oxygenation and viability. J Urol. 2012;187(2):744-750.

18. Etiology of Acute Scrotum at Surgical Exploration in Children, Adolescents and Adults - Journals - NCBI [Online]. Available from: https:// www.ncbi.nlm.nih.gov/labs/articles/1606982/. Accessed June 7, 2017.

19. Kass EJ, Stone KT, Cacciarelli AA, Mitchell B. Do all children with an acute scrotum require exploration? $J$ Urol. 1993;150(2 Pt 2): 667-669.

20. Kaye JD, Shapiro EY, Levitt SB, et al. Parenchymal echo texture predicts testicular salvage after torsion: potential impact on the need for emergent exploration. J Urol. 2008;180(4):1733-1736.

21. Srinivasan A, Cinman N, Feber KM, Gitlin J, Palmer LS. History and physical examination findings predictive of testicular torsion: an attempt to promote clinical diagnosis by house staff. J Pediatr Urol. 2011;7(4):470-474.

22. Ciftci AO, Şenocak ME, Tanyel FC, Büyükpamukçu N. Clinical predictors for differential diagnosis of acute scrotum. Eur J Pediatr Surg. 2004;14(5):333-338.

23. Yang C, Song B, Tan J, Liu X, Wei GH, Wei G. Testicular torsion in children: a 20-year retrospective study in a single institution. ScientificWorldJournal. 2011;11:362-368. 
24. Yu KJ, Wang TM, Chen HW, Wang HH. The dilemma in the diagnosis of acute scrotum: clinical clues for differentiating between testicular torsion and epididymo-orchitis. Chang Gung Med J. 2012;35(1):38-45.

25. Ahmed SJ, Kaplan GW, DeCambre ME. Perinatal testicular torsion: preoperative radiological findings and the argument for urgent surgical exploration. J Pediatr Surg. 2008;43(8):1563-1565.

26. Kaye JD, Shapiro EY, Levitt SB, et al. Parenchymal echo texture predicts testicular salvage after torsion: potential impact on the need for emergent exploration. J Urol. 2008;180(4):1733-1736.
27. Chmelnik M, Schenk JP, Hinz U, Holland-Cunz S, Günther P. Testicular torsion: sonomorphological appearance as a predictor for testicular viability and outcome in neonates and children. Pediatr Surg Int. 2010;26(3):281-286.

28. Samson P, Hartman C, Palmerola R, et al. Ultrasonographic assessment of testicular viability using heterogeneity levels in torsed testicles. $J$ Urol. 2017;197(3):925-930.

29. Barbosa JA, Tiseo BC, Barayan GA, et al. Development and initial validation of a scoring system to diagnose testicular torsion in children. J Urol. 2013;189(5):1859-1864.
Research and Reports in Urology

\section{Publish your work in this journal}

Research and Reports in Urology is an international, peer-reviewed, open access journal publishing original research, reports, editorials, reviews and commentaries on all aspects of adult and pediatric urology in the clinic and laboratory including the following topics: Pathology, pathophysiology of urological disease; Investigation and treatment of

\section{Dovepress}

urological disease; Pharmacology of drugs used for the treatment of urological disease. The manuscript management system is completely online and includes a very quick and fair peer-review system, which is all easy to use. Visit http://www.dovepress.com/testimonials.php to read real quotes from published authors. 